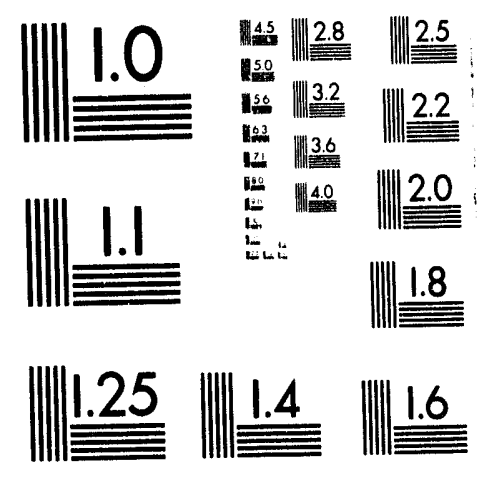



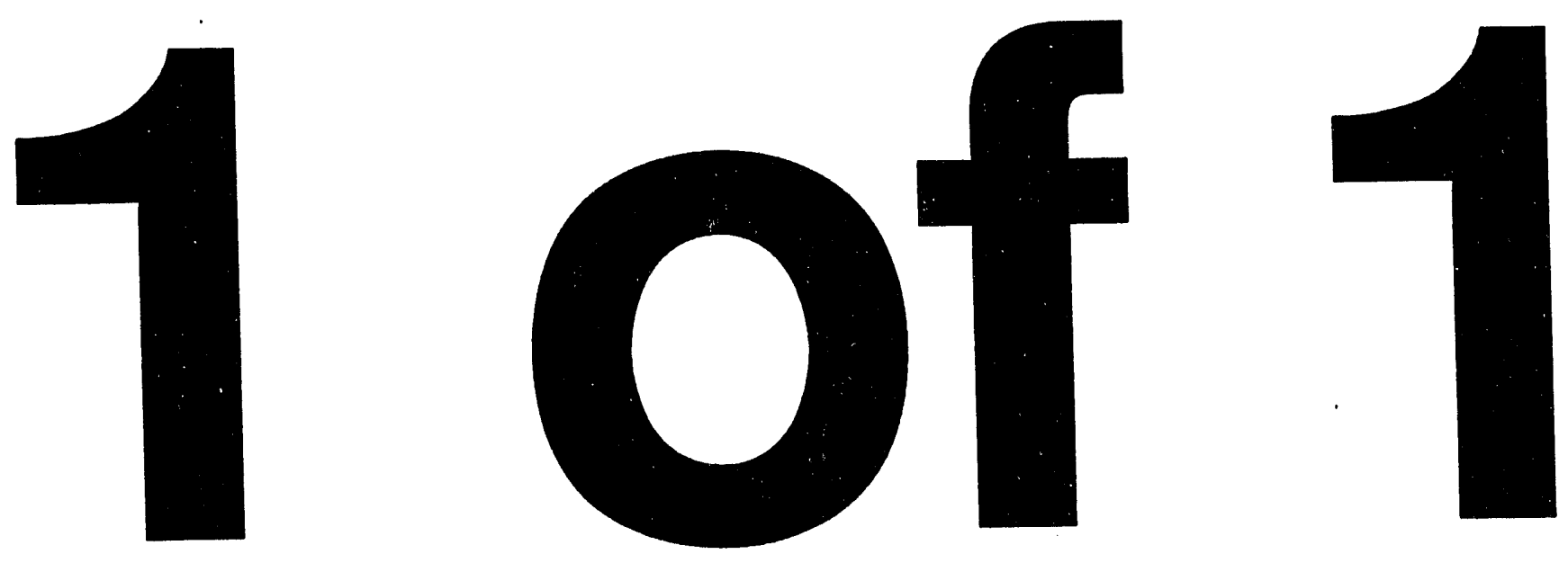


\title{
Photolonization Studies of Organosulfur transient Species
}

\author{
B. Ruscic and J. Berkowitz \\ Chemistry Division, Argonne National Laboratory
}

Photoionization mass spectrometric studies of the transient species $\mathrm{CH}_{2} \mathrm{SH}, \mathrm{CH}_{3} \mathrm{~S}, \mathrm{CH}_{2} \mathrm{~S}$, and HCS have established the heats of formation of these species and their cations, thereby resolving a serious discrepancy between other recent experiments and ab initio calculations in favor of the latter. The isomers $\mathrm{CH}_{2} \mathrm{SH}\left(\mathrm{CD}_{2} \mathrm{SH}\right)$ and $\mathrm{CH}_{3} \mathrm{~S}\left(\mathrm{CD}_{3} \mathrm{~S}\right)$ were prepared in situ by reaction of F atoms with $\mathrm{CH}_{3} \mathrm{SH}\left(\mathrm{CD}_{3} \mathrm{SH}\right)$. Similar successive abstractions, as well as pyrolysis of suitable precursors, were used to generate $\mathrm{CH}_{2} \mathrm{~S}$ and HCS. The adiabatic ionization potentials obtained, together with relevant appearance potentials and some auxiliary data, were sufficient to establish the heats of formation for the cited species.

Drs. B. Ruscic and J. Berkowitz at Argonne National Laboratory used the above method, together with confirmatory data obtained from the dissociative ionization of $\mathrm{CH}_{3} \mathrm{SSCH}_{3}$ into various fragments, to derive the thermochemical properties of these important intermediates occurring in the combustion of sulfur-containing hydrocarbon fuels. Their work was supported by the Division of Chemical Sciences, Office of Basic Energy Sciences.

\section{DISCLAIMER}

This report was prepared as an account of work sponsored by an agency of the United States Ne Government. Neither the United Stess or implied, or assumes any legal liability or responsiemployees, makes any warranty, express or implied, or assumes any legal liability or respoct, or bility for the accuracy, completeness, or usefulness of any information, apparatus, prodect, process disclosed, or represents that its use would not infringe privately owe trade name, trademark, ence herein to any specific commercial product, process, or service by trade name, traderecommanufacturer, or otherwise does not necessarily constitute or imply its enderef The views mendation, or favoring by the United States Government or any agency therect those of the and opinions of authors expressed herein do not United States Government or any agency thereof. 


\title{
PHOTOIONIZATION STUDIES OF ORGANOSULFUR TRANSIENT SPECIES
}

\author{
B. Ruscic and J. Berkowitz \\ Chemistry Division, Argonne National Laboratory
}

Recently there has been a flurry of activity directed at the determination of thermochemical properties of simple organosulfur species. The interest has been at least partly motivated by the need to better understand the combustion of sulfur-containing fuels and the concomitant emission of atmospheric pollutants. The transient species $\mathrm{CH}_{3} \mathrm{~S}, \mathrm{CH}_{2} \mathrm{SH}, \mathrm{CH}_{2} \mathrm{~S}$, and $\mathrm{HCS}$ are believed to play important roles as intermediates in these processes.

We have prepared these transient species in situ by hydrogen abstraction, pyrolysis, or a combination of both methods, and have succeeded in studying them by photoionization mass spectrometry.

The species $\mathrm{CH}_{3} \mathrm{~S}$ and $\mathrm{CH}_{2} \mathrm{SH}$ are isomers. Both can be formed as abstraction products during the reaction of $\mathrm{F}$ atoms with methyl mercaptan $\left(\mathrm{CH}_{3} \mathrm{SH}\right)$, and in photoionization experiments they appear at the same $\mathrm{m} / \mathrm{e}=47 \mathrm{channel}$ (see Fig. 1). The two isomers can be further distinguished by selective isotopic studies, e.g., using $C_{3} S H$, where $C_{3} S$ appears at m/e $=50$, and $C D_{2} S H$ at $\mathrm{m} / \mathrm{e}=49$ (see Figs. 2 and 3). Our values for the adiabatic ionization potentials are: $\mathrm{CH}_{2} \mathrm{SH}, 7.536 \pm$ $0.003 \mathrm{eV} ; \mathrm{CD}_{2} \mathrm{SH}, 7.522 \pm 0.003 \mathrm{eV} ; \mathrm{CH}_{3} \mathrm{~S}, 9.262 \pm 0.005 ; \mathrm{CD}_{3} \mathrm{~S}, 9.268 \pm 0.005 \mathrm{eV}$

For $\mathrm{CH}_{3} \mathrm{~S}$, our value is an improvement on a prior measurement. For the other three species, our measurements represent the first direct detection in photoionization mass spectrometric experiments. From the adiabatic ionization potentials, and other auxiliary data (appearance potentials, an independent $\Delta \mathrm{H}_{\uparrow}$ of $\mathrm{CH}_{3} \mathrm{~S}$ ), we have determined the heats of formation of these species and of their cations. We find that $\mathrm{CH}_{3} \mathrm{~S}$ is more stable than $\mathrm{CH}_{2} \mathrm{SH}$ by $6.3 \pm 2 \mathrm{kcal} / \mathrm{mol}$. Hence, $\mathrm{D}_{\mathrm{o}}\left(\mathrm{H}-\mathrm{CH}_{2} \mathrm{SH}\right)=92.4 \pm 2.0 \mathrm{kcal} / \mathrm{mol}(\leq 94.0 \pm 0.1 \mathrm{kcal} / \mathrm{mol})$ is stronger than $\mathrm{D}_{\mathrm{o}}\left(\mathrm{H}_{3} \mathrm{CS}-\mathrm{H}\right)=86.1 \pm$ $0.6 \mathrm{kcal} / \mathrm{mol}$ by the same quantity. However, $\mathrm{CH}_{2} \mathrm{SH}^{+}$is more stable than $\mathrm{CH}_{3} \mathrm{~S}^{+}$by $33.5 \pm 2.0$ $\mathrm{kcal} / \mathrm{mol}$. This latter value is in agreement with a recent ab initio calculation, but in disagreement with other recent experiments. The a posteriori analysis of the latter experiments shows that $\Delta H_{f_{0}}^{\circ}\left(\mathrm{CH}_{3} \mathrm{~S}\right)$ and $\Delta \mathrm{H}_{f_{0}}^{\circ}\left(\mathrm{CH}_{3} \mathrm{~S}^{+}\right)$were placed too high by about $3.4 \mathrm{kcal} / \mathrm{mol}$, whereas $\Delta \mathrm{H}_{\mathrm{f}_{0}}\left(\mathrm{CH}_{2} \mathrm{SH}^{+}\right)$was placed too low by $5.7 \mathrm{kcal} / \mathrm{mol}$. 
It is interesting to compare the behavior of $\mathrm{CH}_{2} \mathrm{SH}$ and $\mathrm{CH}_{3} \mathrm{~S}$ with their oxygen analogs, $\mathrm{CH}_{2} \mathrm{OH}$ and $\mathrm{CH}_{3} \mathrm{O}$. These analogs, extremely important in combustion processes, were also studied by us recently. There, unlike the case of the sulfur analogs, $\mathrm{CH}_{2} \mathrm{OH}$ is more stable than $\mathrm{CH}_{3} \mathrm{O}$ by $\geq 8.0 \pm 1.2 \mathrm{kcal} / \mathrm{mol}$. Thus $\mathrm{D}_{0}\left(\mathrm{H}-\mathrm{CH}_{2} \mathrm{OH}\right)=95.0 \pm 0.7 \mathrm{kcal} / \mathrm{mol}$, close to $\mathrm{D}_{0}\left(\mathrm{H}-\mathrm{CH}_{2} \mathrm{SH}\right)$, whereas $D_{0}\left(H_{3} \mathrm{CO}-\mathrm{H}\right)=103.1 \pm 1.0 \mathrm{kcal} / \mathrm{mol}$, is significantly larger than $\mathrm{D}_{\mathrm{o}}\left(\mathrm{H}_{3} \mathrm{CS}-\mathrm{H}\right)$. However, $\mathrm{CH}_{2} \mathrm{OH}^{+}$is significantly more stable than $\mathrm{CH}_{3} \mathrm{O}^{+}$, paralleling the situation for the sulfur analogs. Therefore, both $\mathrm{CH}_{3} \mathrm{~S}^{+}$and $\mathrm{CH}_{3} \mathrm{O}^{+}$are metastable. However, whereas both $\mathrm{CH}_{3} \mathrm{~S}^{+}$and $\mathrm{CD}_{3} \mathrm{~S}^{+}$seem relatively long-lived, $\mathrm{CH}_{3} \mathrm{O}^{+}$is very short-lived even in its ground vibrational state (less than $10 \mu \mathrm{s}$ ) and decomposes to $\mathrm{HCO}^{+}+\mathrm{H}_{2}$ through a triplet-singlet surface crossing. Its isotopomer, $\mathrm{CD}_{3} \mathrm{O}^{+}$, shows some marginal stability in its ground vibrational state, presumably due to lower zero point energy and barrier tunneling probability.

Thioformaldehyde, $\mathrm{CH}_{2} \mathrm{~S}$, was observed as a successive abstraction product from the $\mathrm{F}+$ $\mathrm{CH}_{3} \mathrm{SH}$ reaction, and was also prepared by pyrolytic decomposition of two different precursors: methanesulfuryl chloride, $\mathrm{CH}_{3} \mathrm{SCl}$, and methyl disulfide, $\mathrm{CH}_{3} \mathrm{SSCH}_{3}$. The photoionization spectrum of $\mathrm{CH}_{2} \mathrm{~S}$ is shown in Fig. 4. The ionization potential of $\mathrm{CH}_{2} \mathrm{~S}$ was found to be $9.376 \pm 0.003 \mathrm{eV}$, which is a slight improvement over two prior photoelectron spectroscopic studies. The general shape of the photoionization curve is reminiscent of that of its oxygen analog, $\mathrm{CH}_{2} \mathrm{O}$. In both cases the threshold is very abrupt, indicating very little change in geometry upon ionization. In fact, a Franck-Condon analysis of the threshold region in $\mathrm{CH}_{2} S$ indicates that the $C-S$ bond length changes by about $0.03 A$, in very good agreement with recent ab initio calculations. During these experiments we also observed the formation of the HCS+ fragment from $\mathrm{CH}_{2} \mathrm{~S}$. Its appearance potential, reduced to $0 \mathrm{~K}$, was found to be $\leq 11.533 \pm 0.021 \mathrm{eV}$.

$\mathrm{HCS}$ was observed as a successive abstraction product from the $\mathrm{F}+\mathrm{CH}_{3} \mathrm{SH}$ reaction, and also by the reaction of $\mathrm{F}$ atoms with $\mathrm{CH}_{2} \mathrm{~S}$, which was prepared by pyrolysis. Curiously, the former method (nominally three-step) yielded more intensity than the latter, almost certainly due to a very efficient surface reaction. To our knowledge, this study was the first detection of HCS in the gas phase. The photoion yield curve, representing a transition from bent HCS to linear $\mathrm{HCS}^{+}$, has a very extended Franck-Condon progression, with almost vanishing ionization probability at the adiabatic threshold (see Fig. 5). Upon a careful Franck-Condon analysis of the observed progression, we con- 
cluded that the adiabatic ionization potential of HCS is $\leq 7.499 \pm 0.005 \mathrm{eV}$, and possibly $7.412 \pm$ $0.007 \mathrm{eV}$.

The measurements performed on $\mathrm{CH}_{2} \mathrm{~S}$ and $\mathrm{HCS}$, together with those on $\mathrm{CH}_{2} \mathrm{SH}$ and $\mathrm{CH}_{3} \mathrm{~S}$, enabled us to derive the heats of formation of each of these species. An additional valuable check of internal consistency was provided by examining the photodissociative ionization of methyl disulfide, $\mathrm{CH}_{3} \mathrm{SSCH}_{3}$. The possible alternative pairs of products, $\mathrm{CH}_{2} \mathrm{~S}^{+}+\mathrm{CH}_{3} \mathrm{SH}, \mathrm{CH}_{2} \mathrm{SH}^{+}+\mathrm{CH}_{3} \mathrm{~S}$, $\mathrm{CH}_{3} \mathrm{SH}^{+}+\mathrm{CH}_{2} \mathrm{~S}$, and $\mathrm{CH}_{3} \mathrm{SH}_{2}{ }^{+}+\mathrm{HCS}$, each having a different $\mathrm{m} / \mathrm{e}$ as signature, have appearance poteritials that are close to one another. By carefully measuring these differences, the individual heats of formation could be confirmed. Thus, $\Delta \mathrm{H}_{\mathrm{f}}{ }_{0}\left(\mathrm{CH}_{2} \mathrm{~S}\right)=28.3 \pm 2.0 \mathrm{kcal} / \mathrm{mol}(\leq 29.9 \pm 0.9 \mathrm{kcal} / \mathrm{mol})$ and $\Delta H_{f_{0}}^{\circ}(H C S)=71.7 \pm 2.0 \mathrm{kcal} / \mathrm{mol}(\leq 73.3 \pm 1.0 \mathrm{kcal} / \mathrm{mol}, \geq 69.7 \pm 2.0 \mathrm{kcal} / \mathrm{mol})$.

Our heats of formation of the $\mathrm{CH}_{n} \mathrm{~S}$ species discussed above, together with auxiliary data, enable us to calculate various $\mathrm{C}-\mathrm{H}, \mathrm{S}-\mathrm{H}$, and $\mathrm{C}-\mathrm{S}$ bond energies and observe some trends. For example, the values for the $\mathrm{C}-\mathrm{S}$ bond energies clearly indicate that while in $\mathrm{CH}_{3} \mathrm{SH}$ and $\mathrm{CH}_{3} \mathrm{~S}$ this bond energy has a single-bond character $(72.6 \pm 0.7$ and $70.0 \pm 0.6 \mathrm{kcal} / \mathrm{mol}$, respectively), it has a double-bond character in $\mathrm{CH}_{2} \mathrm{~S}(\geq 129.4 \pm 1.1 \mathrm{kcal} / \mathrm{mol}, \leq 131.0 \pm 2.0 \mathrm{kcal} / \mathrm{mol})$ and $\mathrm{HCS}(135.9 \pm 2.0$ $\mathrm{kcal} / \mathrm{mol})$, whereas in $\mathrm{CS}$ it acquires a triple-bond character $(169.8 \pm 0.6 \mathrm{kcal} / \mathrm{mol})$. In $\mathrm{CH}_{2} \mathrm{SH}$, the C-S bond $(89.7 \pm 2.0 \mathrm{kcal} / \mathrm{mol})$ has a bond order slightly higher than one, but it can still be considered as essentially a single bond. Also, it is readily apparent that $\mathrm{C}-\mathrm{H}$ bond energies in $\mathrm{CH}_{3} \mathrm{~S}(48.5 \pm 2.0$ $\mathrm{kcal} / \mathrm{mol})$ and $\mathrm{HCS}(45.7 \pm 2.0 \mathrm{kcal} / \mathrm{mol})$ are significantly lower than those in $\mathrm{CH}_{3} \mathrm{SH}(92.4 \pm 2.0$ $\mathrm{kcal} / \mathrm{mol})$ and $\mathrm{CH}_{2} \mathrm{~S}(94.0 \pm 1.0 \mathrm{kcal} / \mathrm{mol})$. The reason for this behavior is obvious: the $\mathrm{C}-\mathrm{H}$ bond dissociations are accompanied by a strengthening of the C-S bond in the former two cases, but not in the latter two. A similar reasoning applies also to the S.H bond strengths in $\mathrm{CH}_{3} \mathrm{SH}$ and $\mathrm{CH}_{2} \mathrm{SH}$. As a consequence, the sequence $D_{0}\left(H-C_{n} S\right), n=2,1,0$ oscillates between a high and a low value. These effects are similar to those observed previously by us in the $\mathrm{C}_{2} \mathrm{H}_{n}$ and $\mathrm{Si}_{2} \mathrm{H}_{n}$ systems.

All of the heats of formation and ionization potentials of the $\mathrm{CH}_{n} S$ transient species determined here experimentally are in excellent agreement with recent ab initio calculations, and provide a necessary and valuable input for combustion calculations involving organosulfur species. 
Fig. 1. The photoion yield at $\mathrm{m} / \mathrm{e}=47$, corresponding to parent ionization from the isomeric species $\mathrm{CH}_{3} \mathrm{~S}$ and $\mathrm{CH}_{2} \mathrm{SH}$. The wavelength region between the onset at $1645 \AA$ and $-1340 \AA$ is attributable to ionization of $\mathrm{CH}_{2} \mathrm{SH}$. The growth in the region below $\sim 1340 \AA$ is attributable to ionization of $\mathrm{CH}_{3} \mathrm{~S}$.

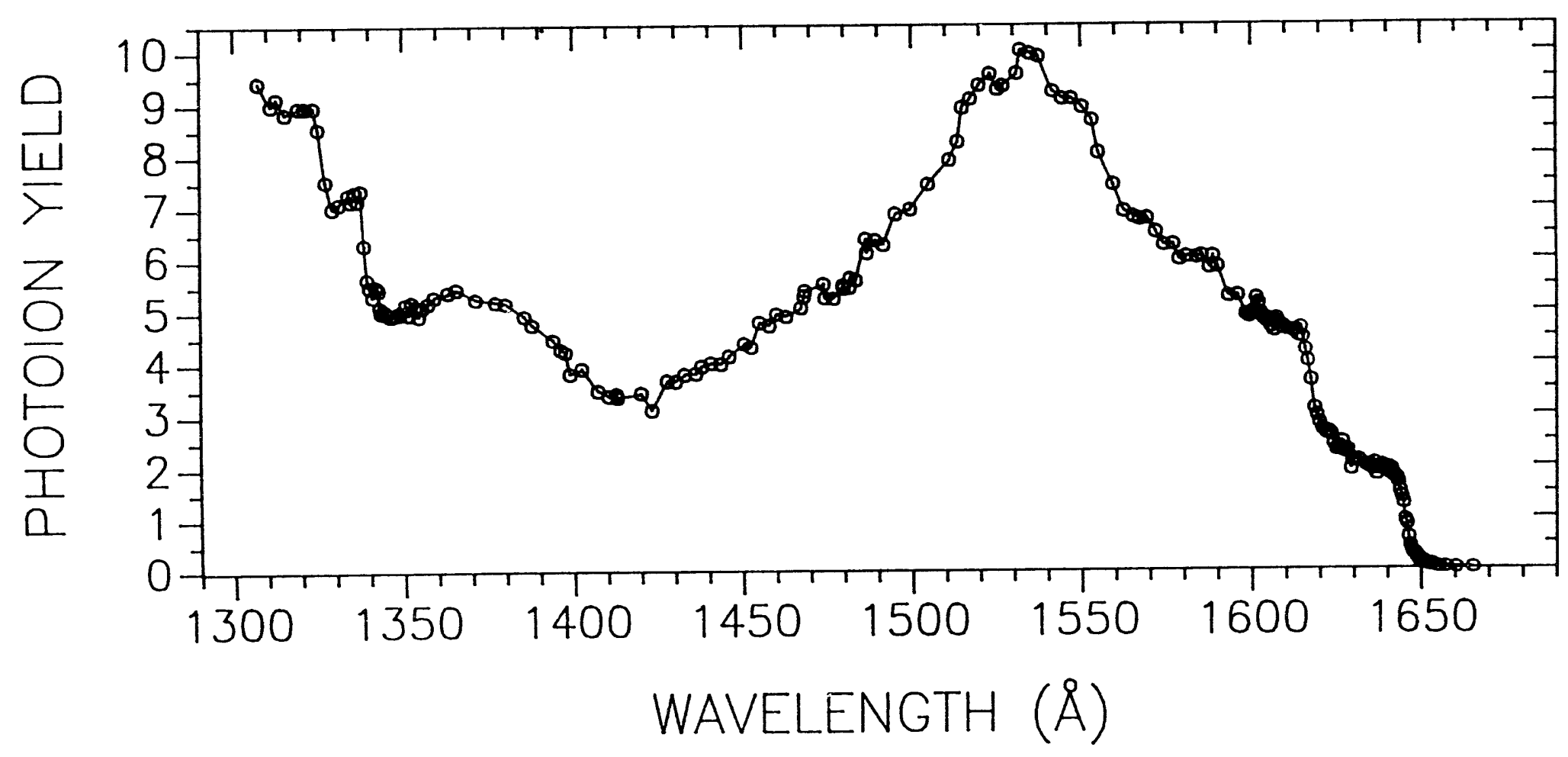




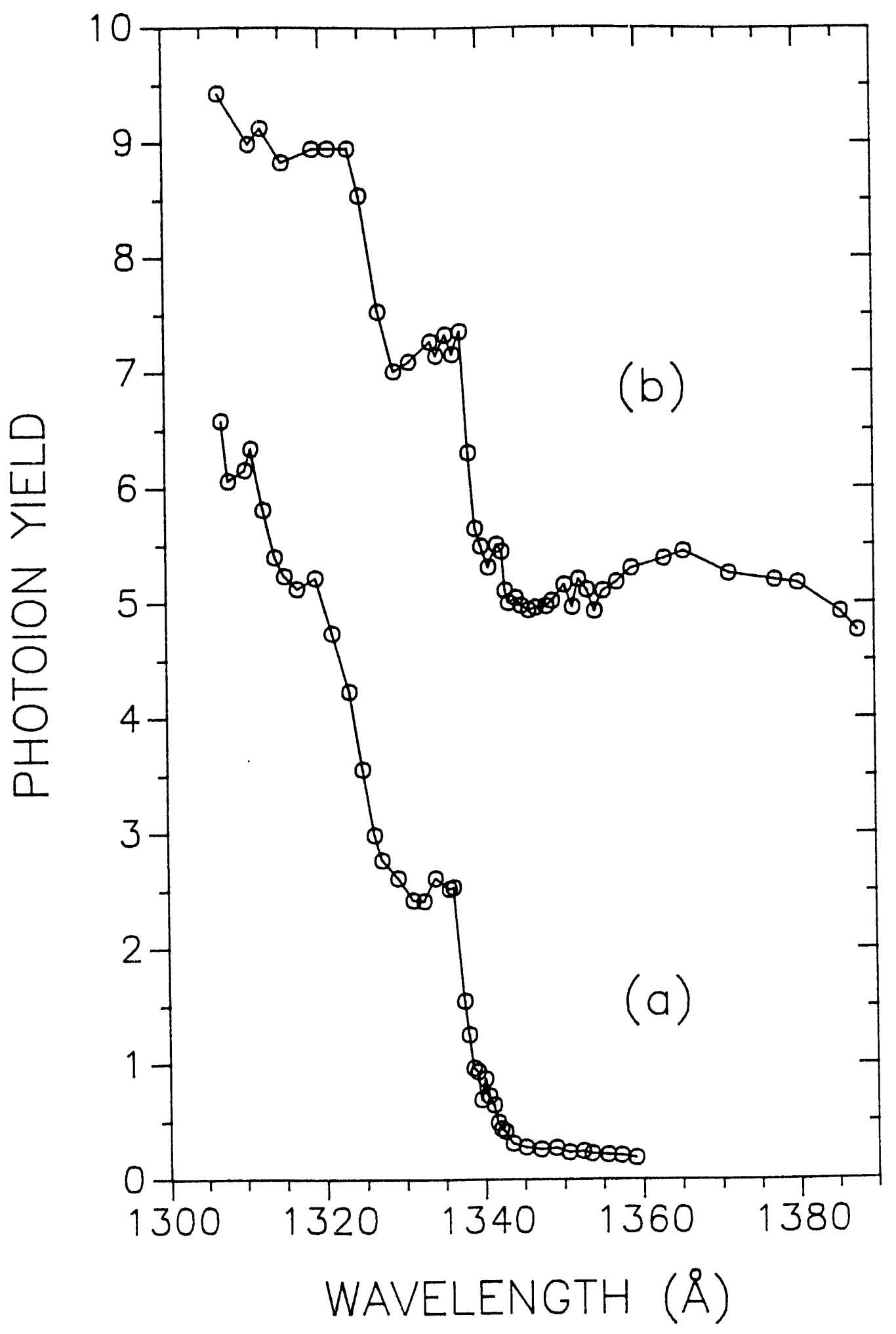

Fig. 2. (a) The photoion yield curve of pure $\mathrm{CD}_{3} S$. (b) An expanded portion of the photoion yield curve from Fig. 1 , in the region where ionization form $\mathrm{CH}_{3} \mathrm{~S}$ begins to contribute to $\mathrm{m} / \mathrm{e}=47$. Note the great similarity in structure between curves (a) and (b). In curve (b), the photoion yield from $\mathrm{CH}_{3} \mathrm{~S}$ "rides" on top of an essentially featureless "background" belonging to $\mathrm{CH}_{2} \mathrm{SH}$. 
Fig. 3. The photoion yield curve of pure $\mathrm{CD}_{2} \mathrm{SH}$. Note the similarity to the curve from Fig. 1 , and the absence of growth in the region -1340 A-1300 A.

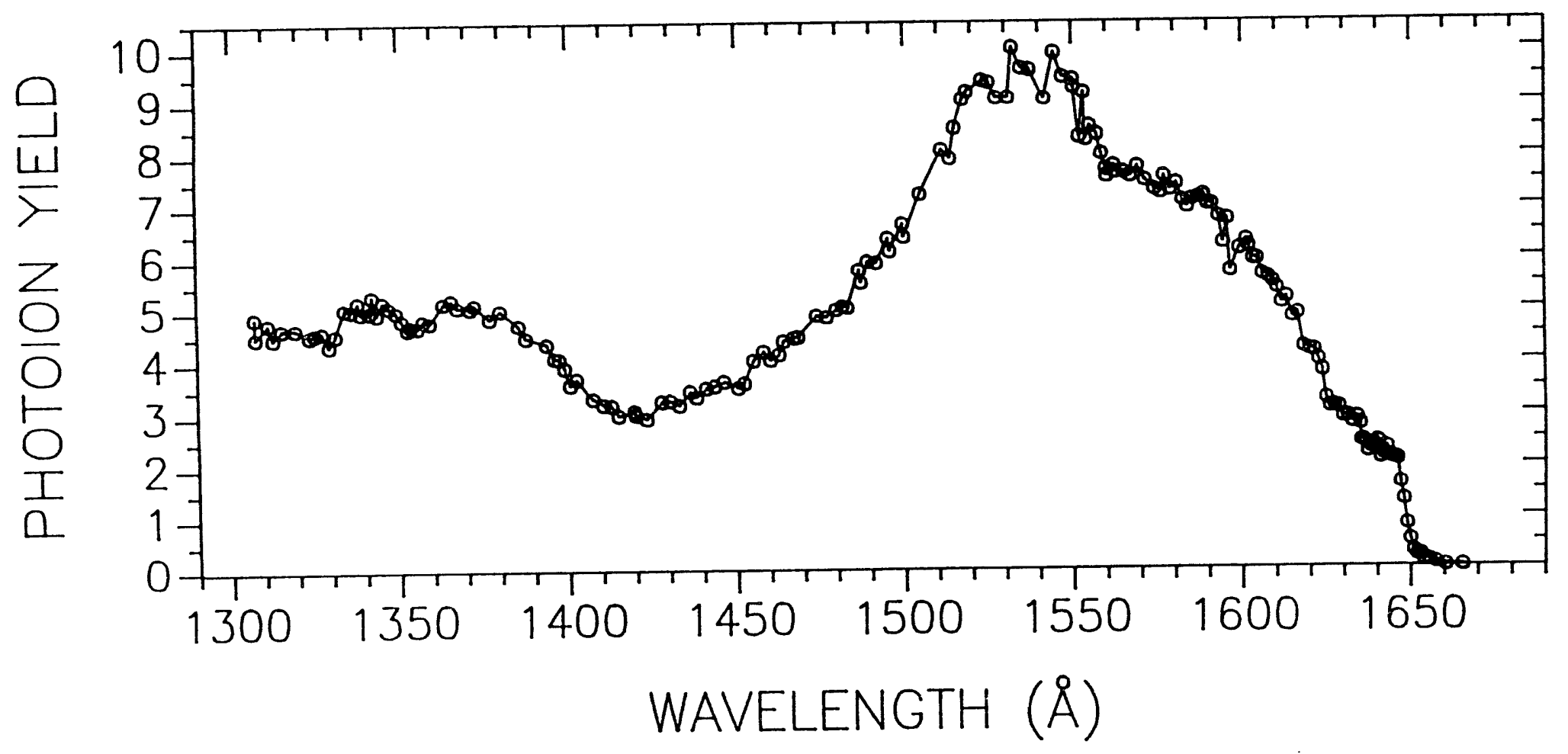


Fig. 4. The photoion yield curve of $\mathrm{CH}_{2} \mathrm{~S}$, obtained by pyrolysis of $\mathrm{CH}_{3} \mathrm{SCl}$. Note the sharp threshold at $1322 \mathrm{~A}$, and the presence of autoionization peaks in the shorter wavelength region.

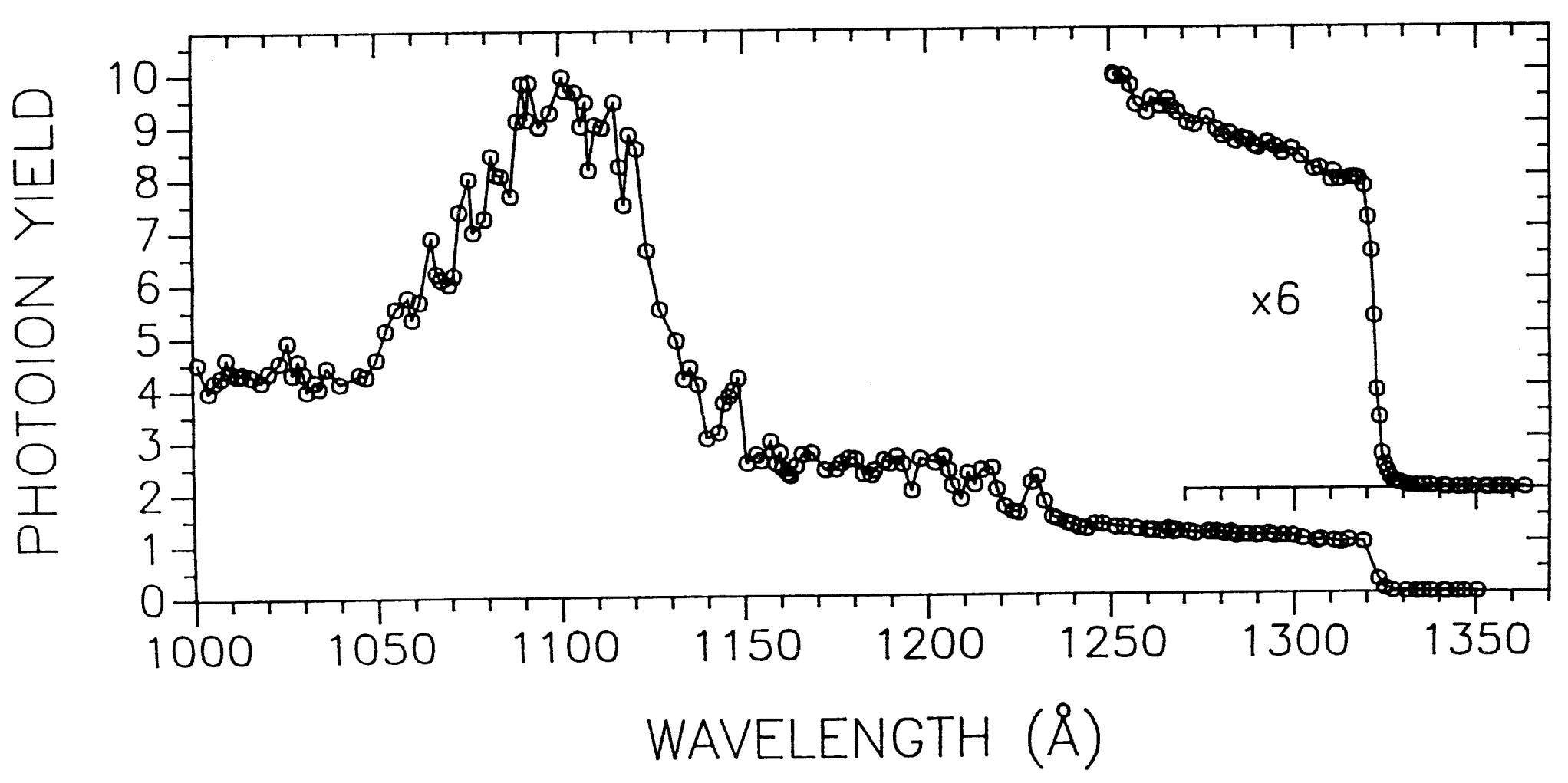


Fig. 5. The photoion yield curve of HCS, obtained by successive hydrogen abstraction reactions from $\mathrm{CH}_{3} \mathrm{SH}$. The region is replete with autoionizing structure. The underlying growth from threshold to shorter wavelength is a consequence of a broad Franck-Condon distribution consistent with a bent-to-linear transition.

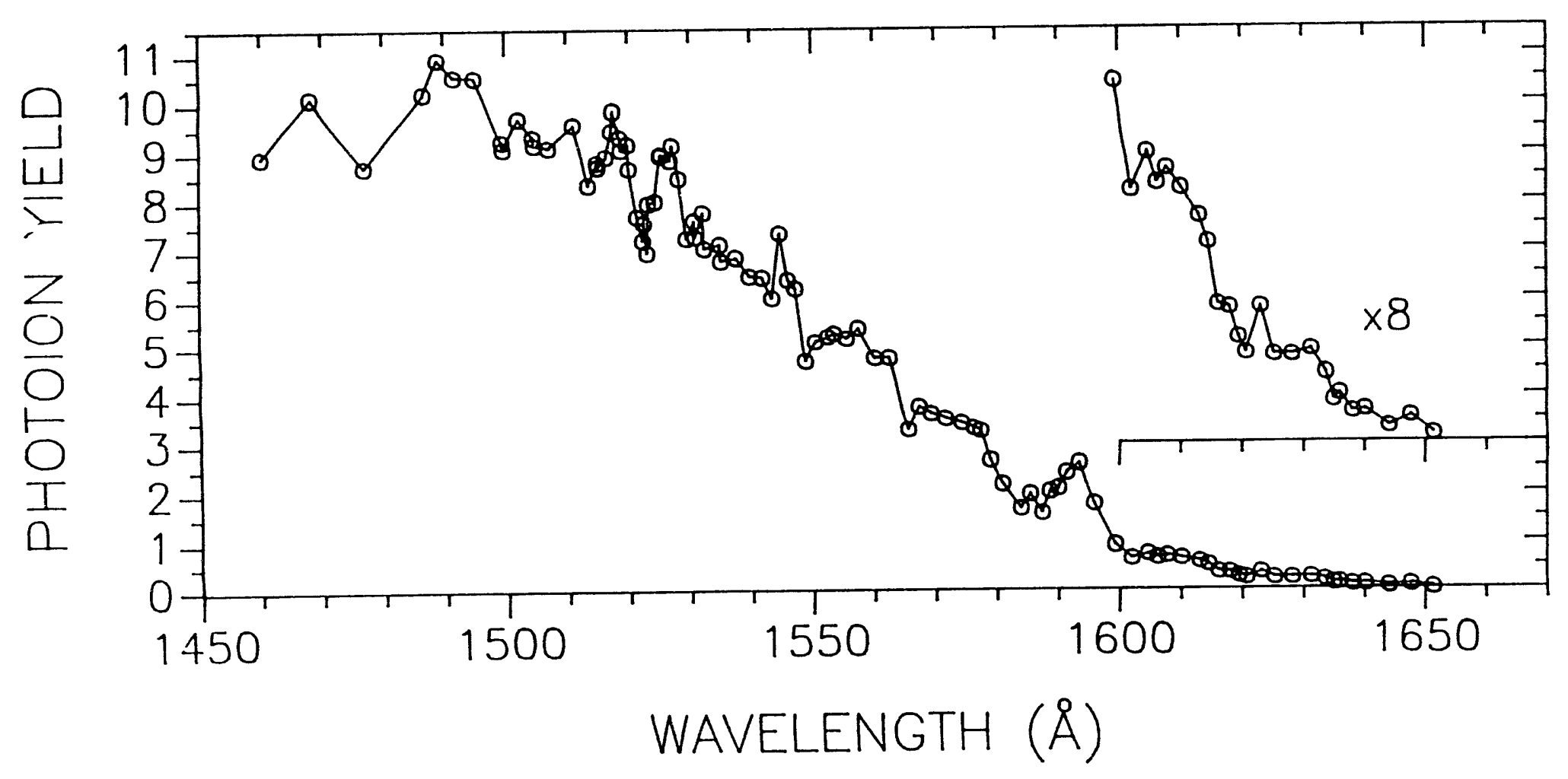




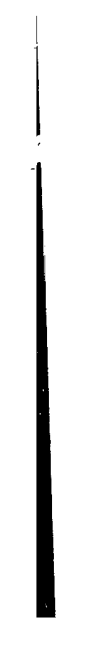

